Article

\title{
Recent Crown Thinning in a Boreal Black Spruce Forest Does Not Reduce Spread Rate nor Total Fuel Consumption: Results from an Experimental Crown Fire in Alberta, Canada
}

\author{
Dan K. Thompson ${ }^{1, *} \mathbb{(}$, Dave Schroeder ${ }^{2}$, Sophie L. Wilkinson ${ }^{3}{ }^{\mathbb{D}}$, Quinn Barber $^{1}{ }^{\mathbb{D}}$, \\ Greg Baxter ${ }^{4}$, Hilary Cameron ${ }^{2}$, Rex Hsieh ${ }^{4}$, Ginny Marshall ${ }^{1}$, Brett Moore ${ }^{1,2} \odot$, Razim Refai ${ }^{4}$, \\ Chris Rodell ${ }^{5}{ }^{\circ}$, Tom Schiks ${ }^{6}$, Gregory J. Verkaik ${ }^{3}{ }^{(1)}$ and Jessica Zerb ${ }^{1}$ \\ 1 Canadian Forest Service, Natural Resources Canada, Northern Forestry Centre, \\ Edmonton, AB T6H 3S5, Canada; quinn.barber@canada.ca (Q.B.); ginny.marshall@canada.ca (G.M.); \\ brett.moore@canada.ca (B.M.); zerb@ualberta.ca (J.Z.) \\ 2 Alberta Agriculture and Forestry, Wildfire Management Branch, Government of Alberta, \\ Edmonton, AB T6H 3S5, Canada; Dave.Schroeder@gov.ab.ca (D.S.); hilary2@ualberta.ca (H.C.) \\ 3 School of Geography and Earth Sciences, McMaster University, Hamilton, ON L8S 4L8, Canada; \\ wilkisl@mcmaster.ca (S.L.W); VERKAIKG@mcmaster.ca (G.J.V.) \\ 4 FPInnovations Wildfire Operations Research Group, Edmonton, AB T6H 3S5, Canada; \\ greg.baxter@fpinnovations.ca (G.B.); Rex.Hsieh@fpinnovations.ca (R.H.); \\ razim.refai@fpinnovations.ca (R.R.) \\ 5 Department of Earth, Ocean, and Atmospheric Sciences, University of British Columbia, \\ Vancouver, BC V6T 1Z4, Canada; crodell@eoas.ubc.ca \\ 6 Department of Forestry, University of Toronto, Toronto, ON M5S 1A1, Canada; tom.schiks@mail.utoronto.ca \\ * Correspondence: Daniel.thompson@canada.ca
}

Received: 31 May 2020; Accepted: 6 July 2020; Published: 9 July 2020

check for updates

\begin{abstract}
A 3.6 ha experimental fire was conducted in a black spruce peatland forest that had undergone thinning the year prior. After $50 \mathrm{~m}$ of spread in a natural stand at $35-60 \mathrm{~m} \mathrm{~min}^{-1}$, the crown fire $\left(43,000 \mathrm{~kW} \mathrm{~m}^{-1}\right.$ intensity using Byram's method) encountered the $50 \%$ stem removal treatment; spread rates in the treatment were $50-60 \mathrm{~m} \mathrm{~min}^{-1}$. Fuel consumption in the control $\left(2.75 \mathrm{~kg} \mathrm{~m}^{-2}\right)$ was comparable to the treatment $\left(2.35 \mathrm{~kg} \mathrm{~m}^{-2}\right)$. Proxy measurements of fire intensity using in-stand heat flux sensors as well as photogrammetric flame heights had detected intensity reductions to $30-40 \%$ of the control. Crown fuel load reductions (compensated by higher surface fuel load) appear to be the most significant contributor to the decline in intensity, despite drier surface fuels in the treatment. The burn depth of $5 \mathrm{~cm}$ in moss and organic soil did not differ between control and treatment. These observations point to the limited effectiveness (likely reductions in crown fire intensity but not spread rate) of stem removal in boreal black spruce fuel types with high stem density, low crown base height and high surface fuel load. The observed fire behaviour impacts differ from drier conifer forests across North America.
\end{abstract}

Keywords: fire behaviour; boreal; crown fire; fuel treatment; thinning; black spruce

\section{Introduction}

Strategies for decreasing home and structure loss in the Wildland-Urban Interface (WUI) have been framed at a variety of scales including building materials [1], vegetation, and environmental characteristics immediately surrounding homes [2], as well as regional scales [3]. This increasing focus on firebrands (embers) as a primary mode of home ignition allows for a two-tiered approach to wildfire 
risk mitigation: a simultaneous focus on homeowners tackling ignition sources on the home exterior and immediate surroundings [1], while wildfire management agencies and municipalities can reduce factors related to firebrand production and spread. Fuel treatments such as thinning and pruning are resource-intensive alternatives to surface prescribed burning in ecosystems with low crown base heights, high surface fuel loads, or dense understory ladder fuels [4]. A candidate ecosystem for thinning and pruning lies in the boreal forest, where the common spruce genus is not adapted to surface fires, and crown fire dominates [5]. In such stands, the goal of fuel treatments such as thinning and pruning is not the wholesale stopping of the fire, but rather an improved suppression environment characterised by lower fire intensity, lower rates of spread, and improved access for suppression resources such as ground crews of aircraft.

Increasing tree spacing alongside lower branch pruning can be expected to lower the likelihood of a surface fire accelerating into a crown fire [6]. The advantages gained from lower crown fuel loading and overall crown fuel reduction should outweigh the increased surface wind speeds, which act to marginally increase surface fire intensity [4]. Increasing tree spacing allows for increased ground-level evaporation and decreased surface fuel moisture via increases in solar radiation and wind [7]. At the same time, more rainfall reaches the surface, and root uptake of duff moisture by trees is decreased [8]. Specific to boreal conifer forests, shade-adapted common feather mosses can experience excess direct sun as a result of thinning operations that change the forest floor light regime. This photostress can lead to moss desiccation and reduced moisture content [9] with likely implications for increasing the depth or rate of duff consumption [10].

Thinning treatments are not expected to stop a wildfire, but rather reduce intensity and rate of spread so that suppression can be successful under conditions where a wildfire in a natural stand would be beyond suppression. Drier surface fuels are likely to occur in these more open thinned stands; as a result, a higher surface intensity has been observed compared to unthinned areas during moderate fire danger conditions [11]. Thinned stands are anticipated to be less flammable than natural stands during extreme wildfire danger when suppression success is unlikely. This reduction in crown fuel load directly leads to lower head fire intensity given the same rate of spread, resulting in increased initial attack success [12]. Lower fuel loads also assist in increasing fireline construction rates [13], allowing for faster mechanical line construction [14], and enhanced aerial suppression effectiveness [15]. Thinned stands are also more accessible for ground crew movement [16] and allow greater ground coverage if sprinklers are deployed [17].

Several case studies in boreal forests indicate that thinning can be effective. Two test burns in jack pine stands in northwestern Canada indicated that thinning and surface fuel cleanup could result in substantially slower and less intense fire behaviour compared to natural stands [18]. Similar tests have been attempted in black spruce stands and suggest similar outcomes as observed in thinned jack pine, albeit under less severe fire weather conditions [19,20]. A case study of a crowning wildfire burning into thinned black spruce indicated that thinning did enhance aerial and ground-based suppression efforts [21]. The impacts of thinning on fire behaviour in black spruce with its uniquely high surface fuel load and under extreme wildfire danger conditions remains unknown. In this study, an experimental fire in thinned black spruce is analysed to determine how the fire behaviour was affected by fuel treatment.

\section{Materials and Methods}

\subsection{Site Description}

The Pelican Mountain experimental fire research site is located in central Alberta, Canada $\left(55.71^{\circ} \mathrm{N}\right.$, $113.57^{\circ} \mathrm{W}$ ), in the southern boreal mixedwood forest of western Canada. The site itself is a $1.9 \mathrm{~km}^{2}$ poorly drained peatland sitting at $640 \mathrm{~m}$ a.s.l (Figure 1). The surrounding area is well-drained aspen forest with numerous headwater streams flowing north from the Pelican Mountain ridge which rises as high as $940 \mathrm{~m}$ a.s.l some $12 \mathrm{~km}$ to the south. The site is almost exclusively peat soil (organic soil 
greater than $40 \mathrm{~cm}$ thick) with a dominant black spruce (Picea mariana) cover and minor stands of larch (Larix laricina). Tree cover is generally dense, with canopy closure $>50 \%$, and dominant tree heights between 5-10 m. Small trees and low branches ( $<1 \mathrm{~m}$ above the ground), even in dominant trees, provide continuous aerial fuels from the ground to tree top. Feather moss (Pleurozium schreberi (Brid.) Mitt.)) is the dominant ground cover, with minor Sphagnum spp. mosses and Cladonia spp. lichens in more open areas. The experimental fire that took place in May 2019 occurred in the northernmost portion of the Pelican Mountain site, where the peatland drains into natural beaver ponds with aspen and mixedwood forest beyond.

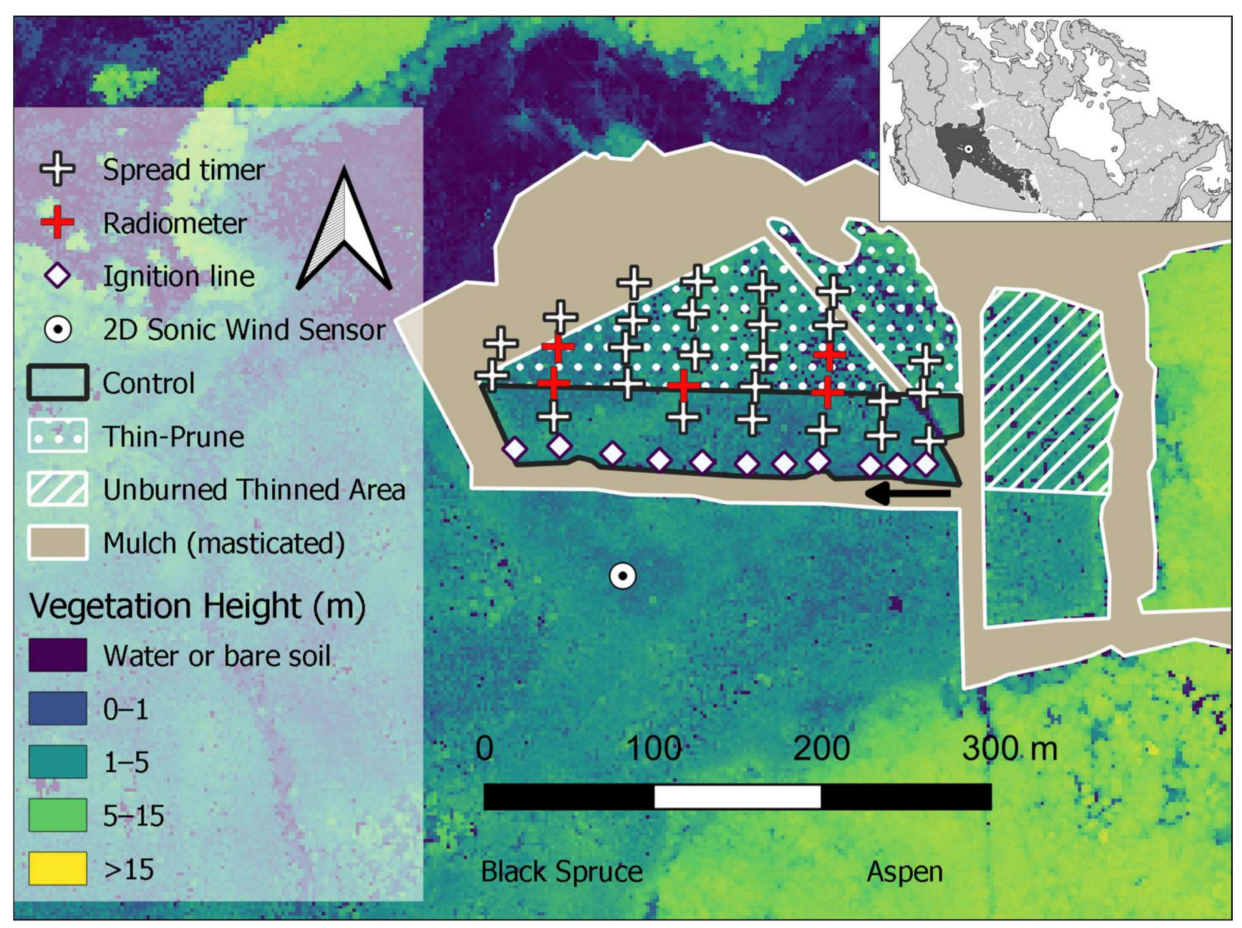

Figure 1. Plot layout and vegetation height. Ignition commenced on the southeast corner and proceeded westward.

The climate of the area is cool and continental, with a mean annual temperature of $1.7^{\circ} \mathrm{C}$ and $460 \mathrm{~mm}$ of annual precipitation. The winters are dry $(120 \mathrm{~mm}$ average snow water equivalent), with snowmelt typically occurring in early April. The month of April is typically dry (22 $\mathrm{mm}$ precipitation average, half as snow), with similarly limited rainfall in the first half of May. During this relatively dry period, deciduous vegetation (such as aspen forest, but also shrubs and grasses) are leafless, leading to high fire spread potential [22] and continuous crown fires in both upland forest as well as peatlands [23]. Fires in the region are 50\% lightning-caused overall, with a median fire size (of fires over $50 \mathrm{ha}$ ) of $390 \mathrm{ha}$, and an overall annual burn rate of $0.5 \%$, or a 200 -year average fire return interval [24]. Human-caused spring fires in the region (defined as prior to deciduous forest leaf-out) are some of the largest and most impactful wildfires in Canada [25].

To test the effectiveness of tree removal thinning in black spruce, the Alberta Wildfire Management Branch selected the Pelican Mountain research site in 2015 as the location for multiple fuel and vegetation manipulation trials and experimental burns. The experimental block (Unit 5) burned in May of 2019 was thinned and pruned (Figure 2) by hand crews over the winter of 2018/2019, and the perimeter was mulched by a mechanical drum mulcher in early 2018 (Figure 1). Unlike mechanical thinning treatments using heavy machinery, the feather moss forest floor was not compacted or disturbed during the winter hand-thinning operation. All residue was piled and burned on-site, resulting in approximately 80 burned spots averaging $1.5 \mathrm{~m}$ in diameter. 


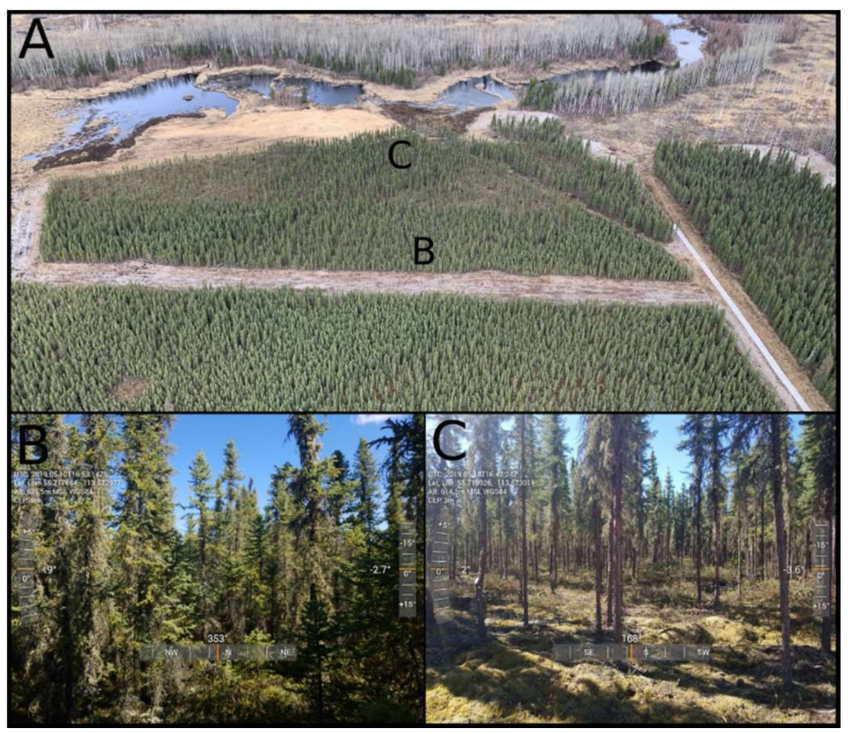

Figure 2. (A) Aerial photo of experimental block Unit 5, (B) control area, and (C) treated area. A preexisting NW-trending cutline was present in the eastern-most portion of the treated area, creating a triangular block that was also thinned.

\subsection{Canopy Height and Fuel Loading}

Measurements of fuel loading were conducted following the standard fixed radius plots in 2018 and spring 2019 in the treatment area before and after thinning. Pre-treatment measurements are assumed to be equal to those in the control.

Multispectral airborne LiDAR data for canopy height mapping and precise block layout was acquired over the Pelican Mountain Research site on 19 August 2018, by the University of Lethbridge ARTEMis lab. The westernmost portion of the hand-thinning treatment was not complete at the time, but most site preparation was complete at the time of the flight. The LiDAR survey was obtained using the Teledyne Optech Titan sensor mounted on a Piper Navajo aircraft. This sensor captures three wavelengths of $1550 \mathrm{~nm}, 1064 \mathrm{~nm}$, and $532 \mathrm{~nm}$. Preprocessing was also completed by the ARTEMis lab using LiDAR Mapping Suite (proprietary software from Teledyne Optech) to generate a calibrated point cloud for each channel. Accuracy for point cloud height data was completed using roof line analysis and had a delta height RMSE of $3.5 \mathrm{~cm}$. For this research, the point clouds from each channel were merged into a single LAS dataset using US Forest Service FUSION/LDV 3.8 software [26]. FUISION/LDV was also used to create a $2.0 \mathrm{~m}$ resolution Digital Elevation Model (DEM) with the GridSurfaceCreate function. The CanopyModel tool was then used to create a $2.0 \mathrm{~m}$ resolution Canopy Height Model by using the highest return in each grid cell normalised with the DEM.

Monochromatic terrestrial LiDAR was collected using a GeoSLAM Zeb-Revo Handheld laser scanner. Scanning at $905 \mathrm{~nm}$ with an acquisition rate of 43,200 points/s and a maximum range of $30 \mathrm{~m}$; before and after burn scans were collected from two control plots and seven test plots. The GeoSLAM collected point clouds with a relative accuracy of $2-3 \mathrm{~cm}$. Data was collected in a multi-loop pattern to resurvey features as often as possible. This pattern resulted in minimised error and increased accuracy of the resulting point cloud. For this research, terrestrial LiDAR was implemented to assist with fuel consumption parameters. Point cloud data was preprocessed using GeoSLAM Hub software and further analysed in FUSION Cloudmetrics.

In the field, a nested plot model (see Supplementary Material for ground plot sampling methods) was used to measure all trees within a specified radius, depending on the diameter at breast height (DBH). Within the specified radius, all trees greater than $1.37 \mathrm{~m}$ in height were measured for height, live crown base height, and DBH. For trees with a DBH greater or equal to $9.0 \mathrm{~cm}$, dead crown base height and canopy widths were also measured. For trees with a DBH less than $9.0 \mathrm{~cm}$, a $3.57 \mathrm{~m}$ 
sampling radius was used unless there were fewer than 20 trees. In this case, a $5.64 \mathrm{~m}$ radius was used to provide a more representative sample of the trees in the area. For all trees greater than $1.37 \mathrm{~m}$ in height with a DBH greater or equal to $9.0 \mathrm{~cm}$, a $11.28 \mathrm{~m}$ sampling radius was used. Canopy fuel load was calculated at the plot level using published allometric equations [27].

Ground cover was assessed visually using a $0.5 \times 0.5 \mathrm{~m}$ vegetation quadrat placed on the ground along three $40 \mathrm{~m}$ transects within each treatment (Figure 1), with measurements every $2 \mathrm{~m}$ (for a total of 63 measurements per treatment). Moss cover was split into the two dominant moss types (genera) in black spruce dominated peatlands, Sphagnum and feather moss, with lichen (Cladonia/Cladina spp.) and litter also included as ground cover types. Moss cover assessments post-fire also accounted for moss burn severity with categories of lightly- and heavily-burned; whereas if moss capitula/moss structure is intact, but there is evidence of burning, the area is classified as lightly-burned (singed); if capitula/structure have been damaged considerably, the area is classified as heavily-burned (burned). Post-fire bare peat (where composition could not be determined) was also included. Depth of burn (DOB) was measured using $20 \mathrm{~cm}$ metal DOB pins placed in the centre of each vegetation survey plot. The top of the pin was made flush with the ground/moss surface, and so the height of the pin above the post-fire ground surface is equal to DOB. Surface volumetric water content (VWC; top $6 \mathrm{~cm}$ of moss and duff) was measured, pre- and post-fire ( $<10 \mathrm{~h}$ pre-fire and 1-2 days post-fire), using an ML3 ThetaProbe by Delta-T Devices (accurate to 1\% VWC) calibrated using curves from [28]. VWC was then converted to gravimetric water content (GWC) using the bulk density of peat core samples taken in $0.1 \mathrm{~m}$ diameter PVC pipes of both Sphagnum and feather moss pre-fire. Depth to seasonal ground ice was measured at each vegetation plot $(n=63$ each in treatment and control) using a thin metal probe, both $48 \mathrm{~h}$ prior to and within $48 \mathrm{~h}$ after the fire.

\subsection{Weather and Fuel Moisture}

Automatic weather stations have been located on site since 2016 to measure precipitation, air temperature, and humidity, though the forest opening is not sufficient to measure wind speeds. Overwinter precipitation was measured $32 \mathrm{~km}$ away at the Wabasca Airport $\left(55.96{ }^{\circ} \mathrm{N}, 113.82{ }^{\circ} \mathrm{W}\right)$. On the day of the fire, an ATMOS-41 2D sonic anemometer and temperature/humidity probe was installed on a tripod $6.1 \mathrm{~m}$ above the ground ( $2 \mathrm{~m}$ above the surrounding trees) $40 \mathrm{~m}$ south of the ignition line (Figure 1), with wind measurements taken every $10 \mathrm{~s}$. Wind speeds were adjusted to $10 \mathrm{~m}$ standard heights using the logarithmic wind profile [29] with an apparent canopy height of $2.8 \mathrm{~m}$, a zero-plane displacement height of $0.52 \mathrm{~m}$, and a friction velocity of $0.93 \mathrm{~m} \mathrm{~s}^{-1}$.

Windsond miniature weather balloons were launched from the southeast corner of the burn site at 14:50 (three hours prior to ignition) to measure the atmospheric conditions above the forest. Temperature, wind, and relative humidity were measured to determine turbulence and stability structures in the atmosphere. Additional measurements were made with a handheld air temperature, humidity, and pressure sensor in a helicopter recording airborne infrared measurements up to $700 \mathrm{~m}$ above ground level.

Destructive fuel moisture samples were collected between 13:00 and 15:00 on the day of ignition, including duff, feather moss tips (uppermost $2 \mathrm{~cm}$ ), Sphagnum moss tips, black spruce needles, surface litter and surface mulch (to the north of the treatment). Each sample was weighed in the field and later dried in a convection oven for $24 \mathrm{~h}$ at $100{ }^{\circ} \mathrm{C}$. Samples were collected in proximity to the ground-based sampling plots, and care was taken not to cause excessive compaction.

\subsection{Ground Observations of Fire Spread and Intensity}

In-fire video cameras, rate-of-spread data loggers, and heat flux sensors were placed around vegetation inventory plots or other observation points within the treated stand (Figure 1). Video cameras were placed in passively cooled steel camera boxes [30] that could withstand the intensity of a crown fire. Ten video cameras located in the treated stand helped ascertain the speed, direction, 
intensity, and duration of the fire. The cameras were pointed towards the untreated area to capture the change in fire behaviour as the fire progressed from the untreated to the treated section of the plot.

A total of 31 temperature-triggered rate-of-spread data loggers (K-type thermocouple, sampling frequency $1 \mathrm{~Hz}$ ) were laid out in a grid format in both untreated and treated parts of the stand and were used to obtain accurate time series fire progression data. The temperature probes from the rate-of-spread loggers were located approximately $30 \mathrm{~cm}$ above the surface. Five temperature-triggered aluminum heat flux sensors (radiometers) [31] (sampling frequency $1 \mathrm{~Hz}$ ) were placed in both untreated and treated sections of the stand to capture the incident heat flux. The sensors were located approximately $50 \mathrm{~cm}$ above the surface.

\subsection{Aerial Observations of Fire Spread and Intensity}

Two helicopters (each nominally $500 \mathrm{~m}$ above the ground) hovered for the duration of the crown fire spread, with visible and infrared video taken to document fire behaviour. Infrared video was taken using a FLIR E40 handheld infrared camera with a dynamic temperature range of up to 0-600 ${ }^{\circ} \mathrm{C}$. Infrared video was able to observe the location of the fire front through thick smoke. Both oblique visible and infrared images from selected video clips were georeferenced and orthorectified using the Monoplotting software [32] against the LiDAR digital elevation model and an orthophoto mosaic obtained from UAV flights in 2018. The fire front was located and digitised at 15 discrete timesteps (an average of once every $25 \mathrm{~s}$ ) and digitised as a polyline with vertices every 10-20 m. A spatial database of the location of the fire front and associated time (in seconds) since the start of the ignition was used to build an interpolated surface of fire spread rate using a triangular interpolation technique in SAGA GIS to produce a $5 \mathrm{~m}$ resolution time of arrival grid. Half of the line vertices were removed, and the remainder converted to point locations prior to interpolation. GPS logger data from the helicopter ignition device was also used as point data in the interpolation. Additionally, flame height was measured using the same monoplotting software along the digitised fire front locations. Since the ground was not visible in the control, the flame base height in the control was sampled off the LiDAR canopy height raster at that location. For the treated thinned areas, the ground was visible, and flame heights were measured using the ground elevation as the height datum. Since the aircraft were observing the fire downwind, the flame angle and length were not quantifiable, but instead, a conservative estimate of flame length equal to flame height was made. Flame height was converted to a measure of fire intensity using the relation of [33] for crown fires:

$$
\mathrm{I}=431 L^{1.5}\left[\mathrm{~kW} \mathrm{~m}^{-1}\right]
$$

\section{Results}

\subsection{Fuel Loading}

The natural, unthinned (control) stand of 12,000 stems ha $^{-1}$ of black spruce amounts to a crown fuel load of $1.3 \mathrm{~kg} \mathrm{~m}^{-2}$ of biomass, or a fuel load $60 \%$ greater than the standard C-2 boreal spruce fuel type crown fuel load of $0.8 \mathrm{~kg} \mathrm{~m}^{-2}$. Litter and fine woody debris contributed an additional $0.39 \mathrm{~kg} \mathrm{~m}^{-2}$ to the surface fuel load, while coarse woody debris ( $>1 \mathrm{~cm}$ diameter) averaged an additional $0.15 \mathrm{~kg} \mathrm{~m}^{-2}$. Observed spatial variability in canopy structure varied widely, with the western edge of the treatment having taller canopy heights, greater fuel load, and lower canopy openness compared to the east (Figure 1). Both the control and treatment ground cover were nearly identical, with between 86 and $88 \%$ cover of feather moss, and between 12 and 13\% cover of Sphagnum mosses, in the control and treated areas, respectively.

\subsection{Fuel Moisture}

Litter and feather moss tips were similar in gravimetric moisture contents in the thinned stand (Figure $3 a ; 7 \pm 2 \%$ ), while feather moss tips were higher in moisture content in the control $(17 \pm 3 \%)$ 
compared to tips in the thinned or control block litter. However, volumetric moisture measurements of the entire upper $6 \mathrm{~cm}$ of feather moss in the control $(5.8 \pm 6.4 \%, n=50)$ and treated areas $(6.0 \pm 4.5 \%$, $n=45$ ) were not different. Duff moisture measurements (below $6 \mathrm{~cm}$ ) across all surface cover types were different, with values in the control $(320 \pm 100 \%)$ higher than those in the treatment $(110 \pm 50 \%)$. One year or older black spruce foliage gravimetric moisture content was $79 \pm 23 \%$, showing considerable variability but on the lower range of the normal value used in the Canadian Forest Fire Behaviour Prediction System of 97\% [34] (Figure 3).
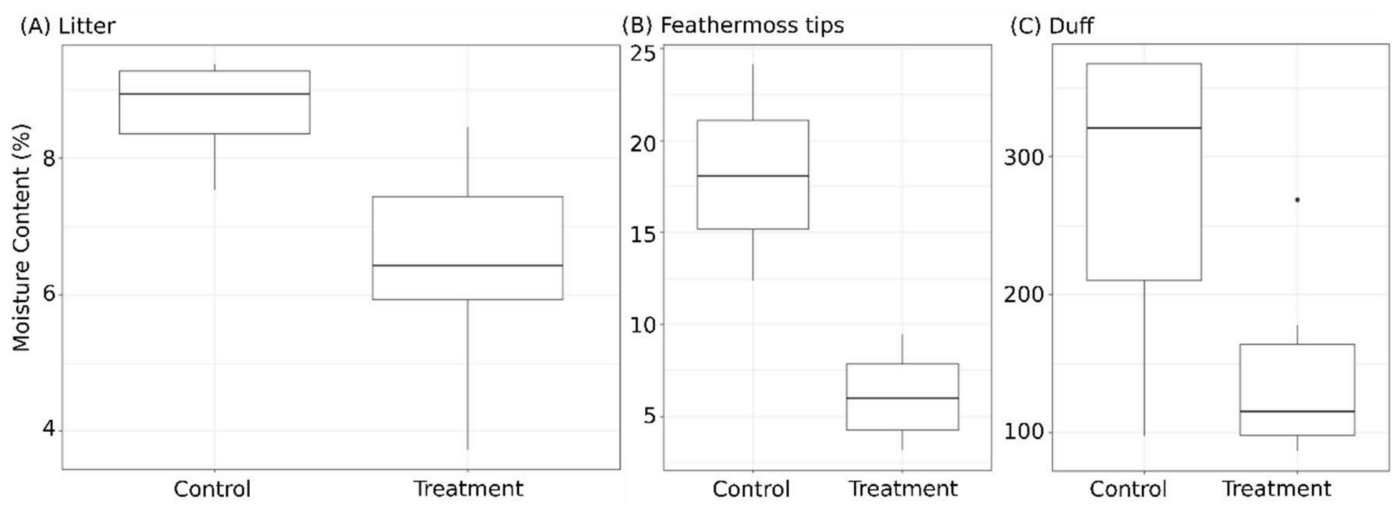

Figure 3. Observed fuel moisture content (\% water by dry weight) for surface litter (A), moss tips (B), and duff $(\mathbf{C})$ greater than approximately $6 \mathrm{~cm}$ from the surface.

\subsection{Fire Weather and Atmosphere}

Cumulative precipitation measured from 1 October 2018 until the ignition date of 11 May 2019 at the Wabasca weather station was $63 \mathrm{~mm}$, or 37\% of the 20-year normal of $169 \mathrm{~mm}$ of precipitation during the same period. Only $3 \mathrm{~mm}$ of precipitation was recorded at the onset of snowmelt around April 11 until May 11. Average air temperature during that same period was $-6.3^{\circ} \mathrm{C}$, very similar to the 20-year normal of $-6.1^{\circ} \mathrm{C}$. The Canadian Fire Weather Index System Drought Code (which correlates well with the water table in boreal peatlands, [35]) was 272 on 1 October 2018 at the nearby Sandy Tower, and reached 331 by May 11. A Drought Code value of 331 represents the 4th driest Drought Code on May 11 recorded for the 36-year record at Wabasca, corresponding to a 1 in 9-year dryness event using an empirical plotting position exceedance methodology [36]. Similarly, the Buildup Index (a harmonic mean of the Drought Code and Duff Moisture Code) was 71, the second highest on record and only 10 points lower than the May 112016 values, corresponding to the dry conditions causing extensive black spruce forested peatland burning during the very large 2016 Fort McMurray wildfire some $175 \mathrm{~km}$ to the northeast $[37,38]$.

Synoptic conditions on May 11 were dominated by an upper air ridge that was present over the area with accompanied subsidence aloft. The subsidence allowed for clear conditions and, as a result, nighttime cooling reached a minimum air temperature of $2.8^{\circ} \mathrm{C}$ at $06: 00$ local time on the morning of May 11, but relative humidity reached only a maximum of $76 \%$ at the same time, suggesting limited nighttime recovery of fine fuel moisture. Clear skies and strong surface heating increased the air temperature to $20^{\circ} \mathrm{C}$ by 13:00 local time with a relative humidity of $22 \%$, and light SE winds at $5 \mathrm{~km}$ with gusts to $22 \mathrm{~km} \mathrm{~h}^{-1}$ (Figure 4 ).

The 13:00 local time Canadian Fire Weather Index values were, daily, Fine Fuel Moisture Code 93.6, Buildup Index 69.6, and Fire Weather Index 27. Observed gustiness was driven by convective turbulence that was present during the latter half of the day, and during the time of the burn, due to the combination of a warm surface and warm air (Figure 4). Convective turbulence created a well-mixed boundary layer (the lowermost portion of the atmosphere), attributing to large variance in the mean wind speed at the surface. The top of the boundary layer was at roughly $2400 \mathrm{~m}$ above ground level, above which a weak inversion inhibited the rise of the convective thermals (Figure 4). In the 30 minutes 
prior to ignition at 17:49, the $10-\mathrm{m}$ wind speed was $10.8 \mathrm{~km} \mathrm{~h}^{-1}$. During that 30 min period, only two $10 \mathrm{~s}$ gusts of $23 \mathrm{~km} \mathrm{~h}^{-1}$ were recorded. With the lighter observed winds of $5 \mathrm{~km} \mathrm{~h}^{-1}$ at 13:00 on May 11, the calculated Initial Spread Index of 8 increased to 18 if using gust wind speeds. This transient increase in winds increased the expected rate of spread in boreal spruce (C-2) fuels from $10 \mathrm{~m} \mathrm{~min}^{-1}$ to $28 \mathrm{~m} \mathrm{~min}^{-1}$. By the time of ignition, air temperature was $22.2{ }^{\circ} \mathrm{C}$ and relative humidity $18.7 \%$.

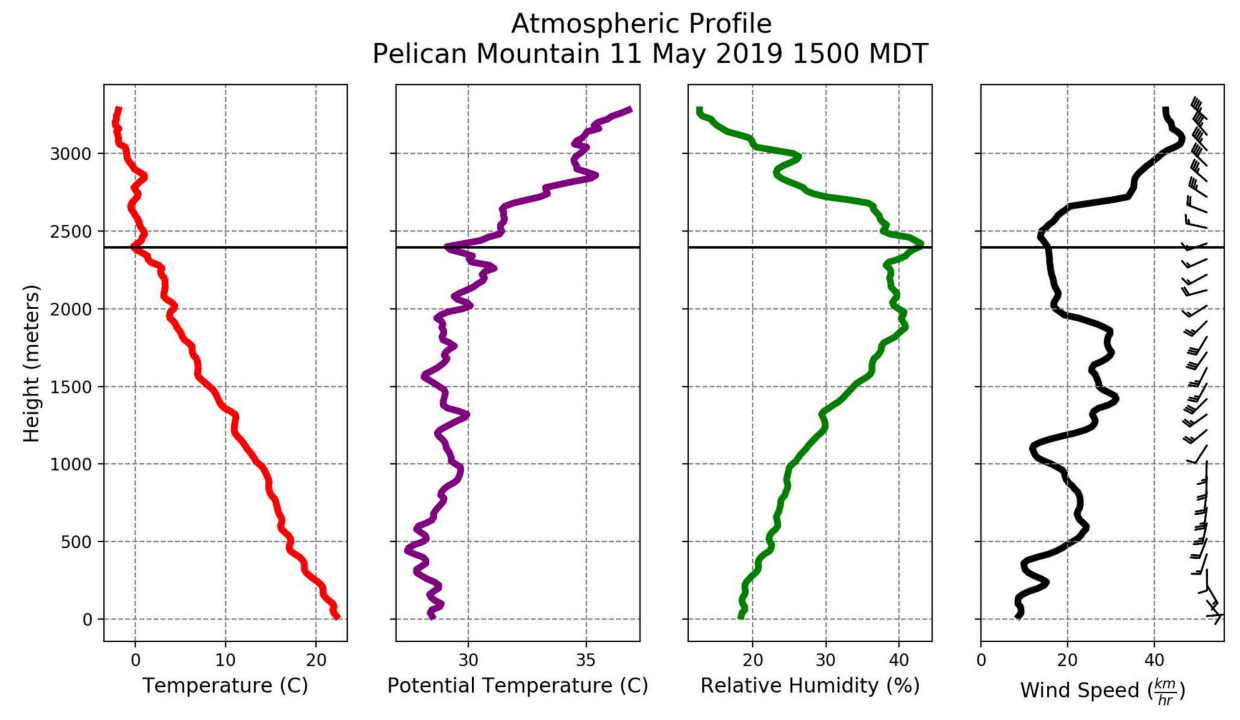

Figure 4. Radiosonde profile launched on-site three hours prior to ignition.

\subsection{Ignition and Spread Rate}

Ignition by heli-torch was initiated at 17:49:03 (from here onwards zero seconds), and the $263 \mathrm{~m}$ long ignition line was largely complete by 17:50:54 (111 s; Figure 5), except the westernmost $45 \mathrm{~m}$ that was ignited at 17:52:46 (223 s). By 360 s after ignition, the crown fire was largely complete, and only surface fires in the mulch to the north as well as flanking fires in the westernmost control and treatment remained. For the six minutes of peak crown fire from 17:49 to 17:55, the 10-m open wind speed increased to $12 \mathrm{~km} \mathrm{~h}^{-1}$, but two distinct gusts recorded in the $10 \mathrm{~s}$ wind record of 26.7 , and $26.9 \mathrm{~km} \mathrm{~h}^{-1}$ were recorded at 17:52:30 and 17:54:20. In the eastern portion of the plot, fire progression as interpolated from in situ observations and airborne observations averaged $34 \mathrm{~m} \mathrm{~min}^{-1}$ (arithmetic average across the $5 \mathrm{~m}$ arrival time grid) in the control stand (50 m long), and averaged approximately $50 \mathrm{~m} \mathrm{~min}^{-1}$ in the treatment stand for its $70 \mathrm{~m}$ length (Figure 5). The western half of the plot, despite a later ignition time, burned much faster through the control $\left(68 \mathrm{~m} \mathrm{~min}^{-1}\right)$ and treatment $\left(60 \mathrm{~m} \mathrm{~min}^{-1}\right)$ than the eastern half. Contra-flow winds from the counter-clockwise rotation of the western head fire were observed in airborne and in-fire footage; subsequently, the centre saw far lower rates of spread over a narrow area of $23 \mathrm{~m} \mathrm{~min}^{-1}$ and $39 \mathrm{~m} \mathrm{~min}^{-1}$ in the control and treatment, respectively. Flank fire rates of spread in the control averaged $15 \mathrm{~m} \mathrm{~min}^{-1}$, the treatment $9 \mathrm{~m} \mathrm{~min}^{-1}$, and mulch surface fires of $5 \mathrm{~m} \mathrm{~min}^{-1}$. Expected head fire rates of spread (using a standard boreal spruce C-2 model) for a wind speed of $12 \mathrm{~km} \mathrm{~h}^{-1}$ was $20 \mathrm{~m} \mathrm{~min}^{-1}$, which increased to $43 \mathrm{~m} \mathrm{~min}^{-1}$ if the gust wind speeds of $26 \mathrm{~km} \mathrm{~h}^{-1}$ are used in the model. 

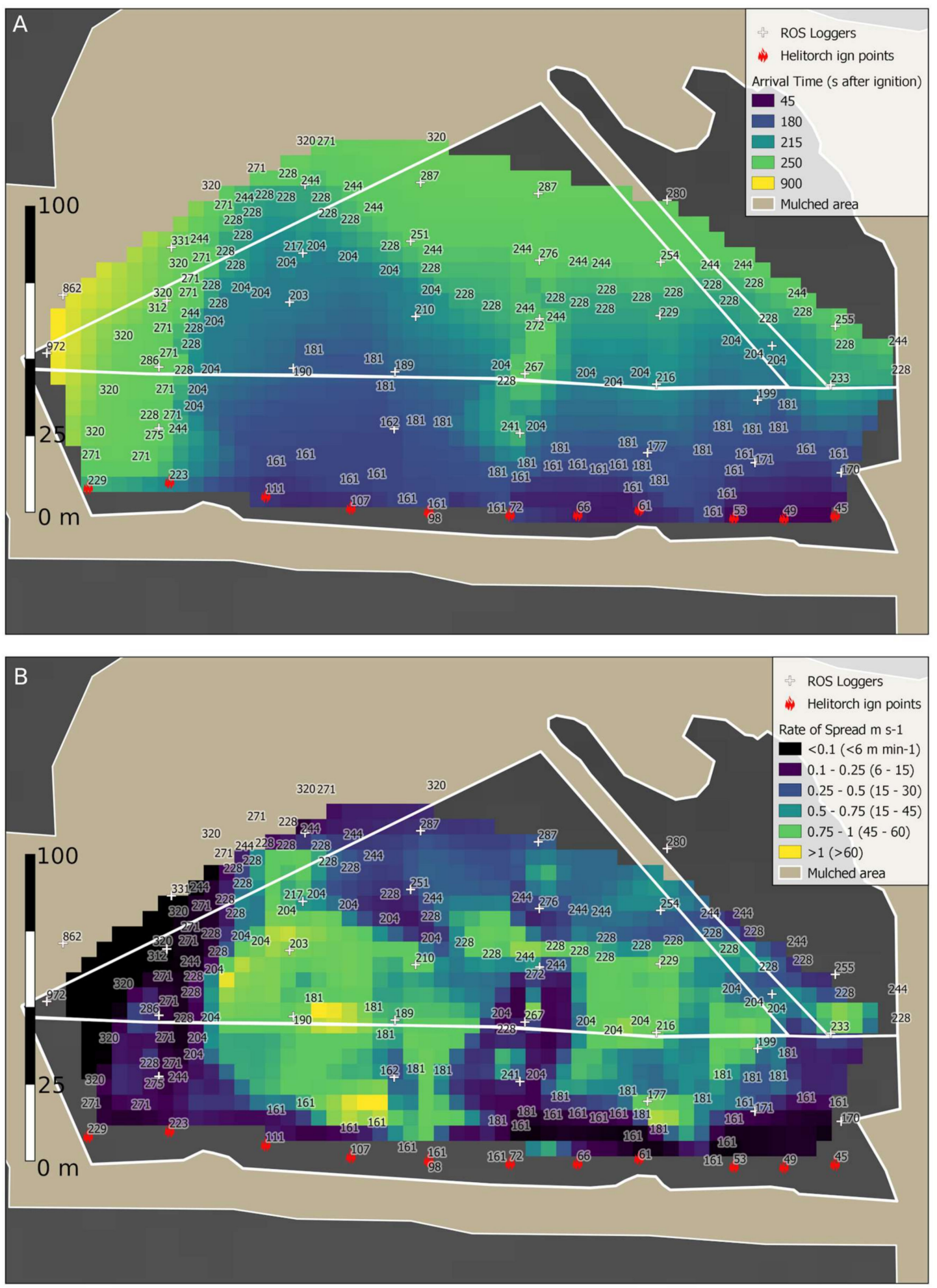

Figure 5. Interpolated fire arrival time (Panel A) and fire rate of spread (Panel B) from a combination of in-fire measurements and oblique photography. The southern polygon containing the ignition points is the control stand, and all areas past the east-west line $50 \mathrm{~m}$ into the control were treated. The pre-existing cutline running NW through the eastern treated area is also shown. Numbers correspond to points of known fire arrival time (seconds after aerial ignition commenced). Note that a fully continuous colour ramp from [39] is used for this and all figures, with mid-point colours of ranges shown in the legend for clarity. 


\subsection{Fuel Consumption and Fire Intensity}

Canopy consumption was observed as nearly 100\% in all areas of head and flank, but was not directly quantified. Surface depth of burn was measured immediately after the safe passage of the crown fire (within 30 minutes of ignition) when only patchy residual smouldering was occurring. Average depth of burn for the control was $5.9 \pm 4.2 \mathrm{~cm}$, and in the thinned treatment $5.4 \pm 4.0 \mathrm{~cm}$ (Figure 6a). Nearly 100\% of feather moss burned to some extent, while only 50\% of Sphagnum moss areas had any combustion whatsoever. Feather moss-covered areas had the highest mean depth of burn of $6.8 \pm 3.9 \mathrm{~cm}$, followed by lichen-covered areas with an average of $4.9 \pm 1.8 \mathrm{~cm}$. Sphagnum-covered areas had a depth of burn of only $0.51 \pm 0.94 \mathrm{~cm}$, where Sphagnum in situ near-surface volumetric water content was $9.0 \pm 6.8 \%$, and feather moss was $5.9 \pm 5.5 \%$. Given an average bulk density for near-surface feather moss (the far dominant surface cover and largest depth of burn) of $18 \mathrm{~kg} \mathrm{~m}^{-3}$ [40], the mean total ground layer consumption was $1.06 \mathrm{~kg} \mathrm{~m}^{-2}$ of total biomass in the control and $0.97 \mathrm{~kg} \mathrm{~m}^{-2}$ in the treated area. Fifth percentile return heights from terrestrial LiDAR show trends similar to standard depth of burn measurements (Figure 6a,b). A qualitative relationship between depth of burn and change in return heights can be drawn as return height elevations range from 0 to $25 \mathrm{~cm}$. In agreement with depth of burn metrics, post-burn scans show an overall decrease in most ground cover fuel elevation.
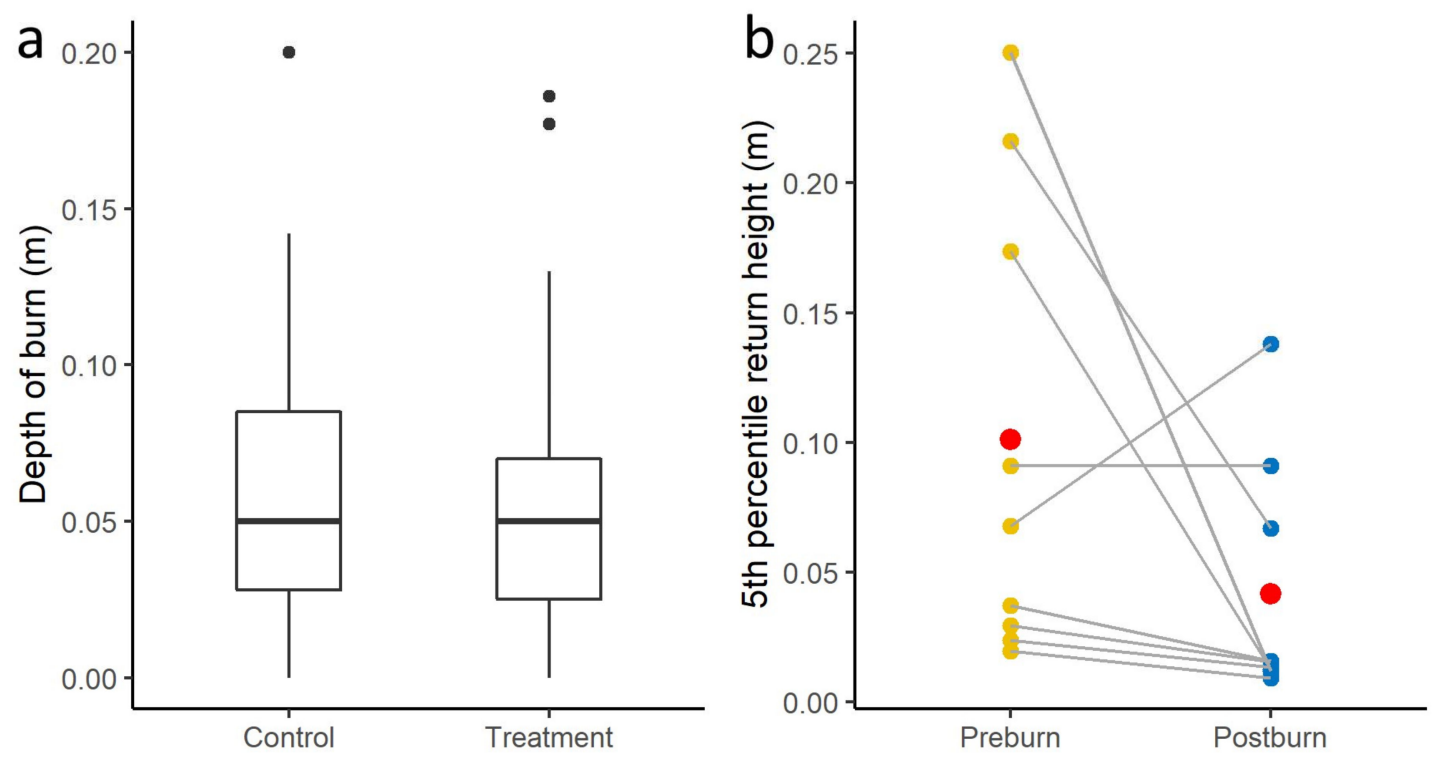

Figure 6. (a) Observed moss and organic soil consumption depth as measured by burn pins, and (b) corresponding decrease in 5th percentile LiDAR return heights. Red dots represent means of all LiDAR collection sites $(n=9)$; grey lines between dots show site-wise change.

Depth to the concrete layer of seasonal ground ice was variable between ground cover types, but not significantly different between the control and treatment (mean $=26 \pm 8.2$ and $26.5 \pm 11 \mathrm{~cm}$, respectively). Sphagnum groundcover was resistant to combustion without regard to depth to ice whereas depth of burn in feather moss tended to weakly increase as depth to ice increased (Figure 7).

Head fire intensity is measured typically using fuel consumption in both the canopy and all surface and ground fuels, including feather moss [41]. Total fuel consumption alongside the median gridded rate of spread from Figure 5 resulted in calculated head fire intensities (east and west portions only) of $43,000 \mathrm{~kW} \mathrm{~m}^{-1}$ in the control and $41,000 \mathrm{~kW} \mathrm{~m}^{-1}$ in the treatment, meaning that the treatment intensity was $94 \%$ of that in the control (Table 1). Incorporating only the canopy fuels, litter, and fine surface woody debris and using the same rate of spread values, the intensity in the control was calculated as 27,000 and $90 \%$ of the control value in the treated stand, or $24,000 \mathrm{~kW} \mathrm{~m}^{-1}$. Median flank fire 
intensities calculated by Byram's method were between $6000 \mathrm{~kW} \mathrm{~m}^{-1}$ in the treatment and 14,000 $\mathrm{m}^{-1}$ in the control.

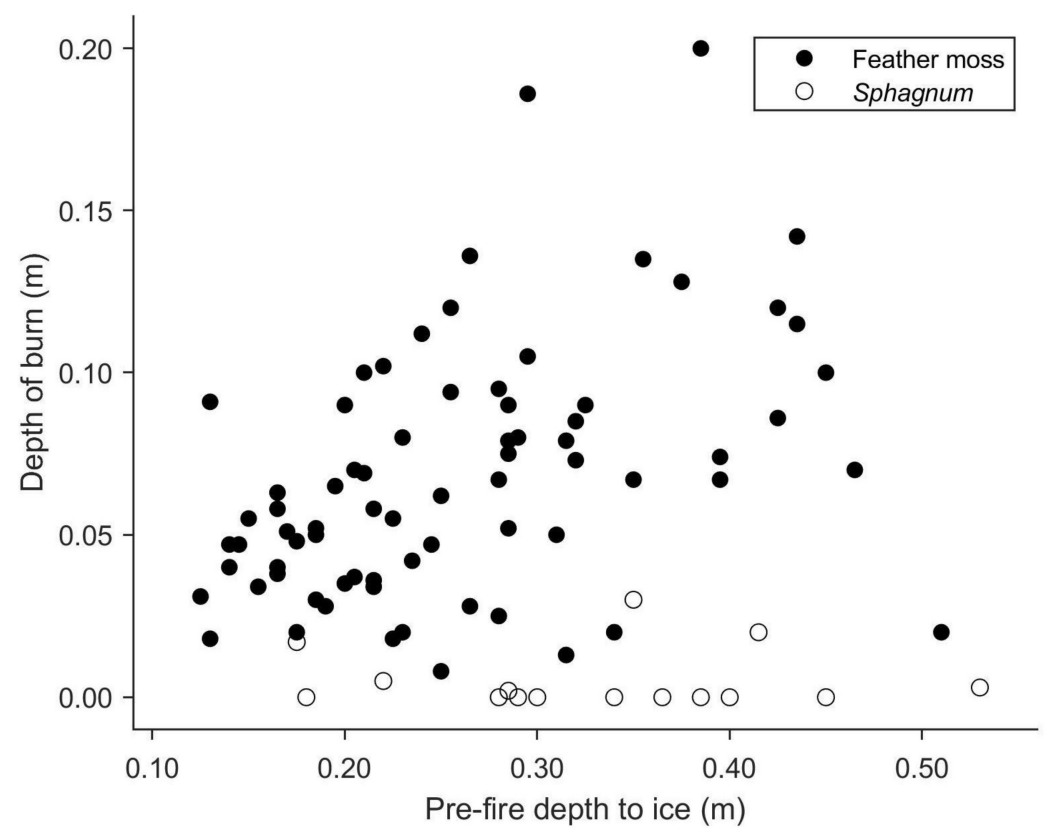

Figure 7. Manually measured moss depth of burn as a function of pre-fire depth to ice. Feather moss linear regression: $\mathrm{DOB}=0.18 *$ depth to ice $+0.02 ; \mathrm{R}^{2}=0.18$. Sphagnum: $\mathrm{DOB}=-0.003^{*}$ depth to ice + $0.006 ; \mathrm{R}^{2}=0.0012$.

Table 1. Fuel loading and fire behaviour characteristics between the control and the treated areas. The ratio of the treatment to the control is also shown.

\begin{tabular}{|c|c|c|c|}
\hline & Control & Treatment & Treat:Control Ratio \\
\hline Median stand height (m) & 4.6 & 6.2 & 1.35 \\
\hline Stem density (stems ha ${ }^{-1}$ ) & 12,000 & 2300 & 0.19 \\
\hline Crown bulk density $\left(\mathrm{kg} \mathrm{m}^{-3}\right)$ & 0.28 & 0.1 & 0.35 \\
\hline Canopy fuel load $\left(\mathrm{kg} \mathrm{m}^{-2}\right)$ & 1.3 & 0.62 & 0.48 \\
\hline Litter load $\left(\mathrm{kg} \mathrm{m}^{-2}\right)$ & 0.29 & 0.46 & 1.59 \\
\hline Fine woody debris $\left(\mathrm{kg} \mathrm{m}^{-2}\right)$ & 0.1 & 0.3 & 3.00 \\
\hline Coarse woody debris $\left(\mathrm{kg} \mathrm{m}^{-2}\right)$ & 0.15 & 0.15 & 1.00 \\
\hline Total flaming fuel load $\left(\mathrm{kg} \mathrm{m}^{-2}\right)$ & 1.69 & 1.38 & 0.82 \\
\hline Mean depth of burn (cm) & 5.9 & 5.4 & 0.92 \\
\hline Duff consumption $\left(\mathrm{kg} \mathrm{m}^{-2}\right)$ & 1.06 & 0.97 & 0.92 \\
\hline Total fuel consumption $\left(\mathrm{kg} \mathrm{m}^{-2}\right)$ & 2.75 & 2.35 & 0.85 \\
\hline Head fire rate of spread $\left(\mathrm{m} \mathrm{min}^{-1}\right)$ & 51 & 56 & 1.10 \\
\hline Flank fire rate of spread $\left(\mathrm{m} \mathrm{min}^{-1}\right)$ & 16 & 8 & 0.50 \\
\hline Byram's fire intensity $\left(\mathrm{kW} \mathrm{m}^{-1}\right)$ canopy plus surface & 26,575 & 23,828 & 0.90 \\
\hline Fire intensity foliage only $\left(\mathrm{kW} \mathrm{m}^{-1}\right)$ & 20,443 & 10,705 & 0.40 \\
\hline Fire intensity using total fuel load $\left(\mathrm{kW} \mathrm{m}^{-1}\right)$ & 43,275 & 40,611 & 0.94 \\
\hline Heat flux sensor peak (10 s average) $\left(\mathrm{kW} \mathrm{m}^{-2}\right)$ & 673 & 70 & 0.10 \\
\hline Heat flux sensor total $\left(\mathrm{kJ} \mathrm{m}^{-2}\right)$ & 3954 & 1163 & 0.29 \\
\hline Median flame height (m) & 11.4 & 5.5 & 0.48 \\
\hline Median intensity from flame height $\left(\mathrm{kW} \mathrm{m}^{-1}\right)$ & 16,590 & 5559 & 0.34 \\
\hline
\end{tabular}

Median observed flame heights from the oblique aerial video (Figure 8$)$ in the control area $(n=164)$ were $11.4 \mathrm{~m}$ tall, fully $6.8 \mathrm{~m}$ taller than the median tree height of $4.6 \mathrm{~m}$ in the control. Using the relation 
between flame length (conservatively estimating flame length equal to height) and intensity from [33], a median fire intensity of $16,500 \mathrm{~kW} \mathrm{~m}^{-1}$ was observed across the entire control area. Similarly, in the treatment, a median flame height of $5.5 \mathrm{~m}$ and a median intensity of $5500 \mathrm{~kW} \mathrm{~m}^{-1}$ was observed. Overall, the treated area was observed to have flame heights only $34 \%$ of those in the control (Table 1 ). Smaller flame heights in the mulch area showing head fire and flanking fire behaviour of $3.1 \mathrm{~m}$ and $1.9 \mathrm{~m}$ were observed, respectively.

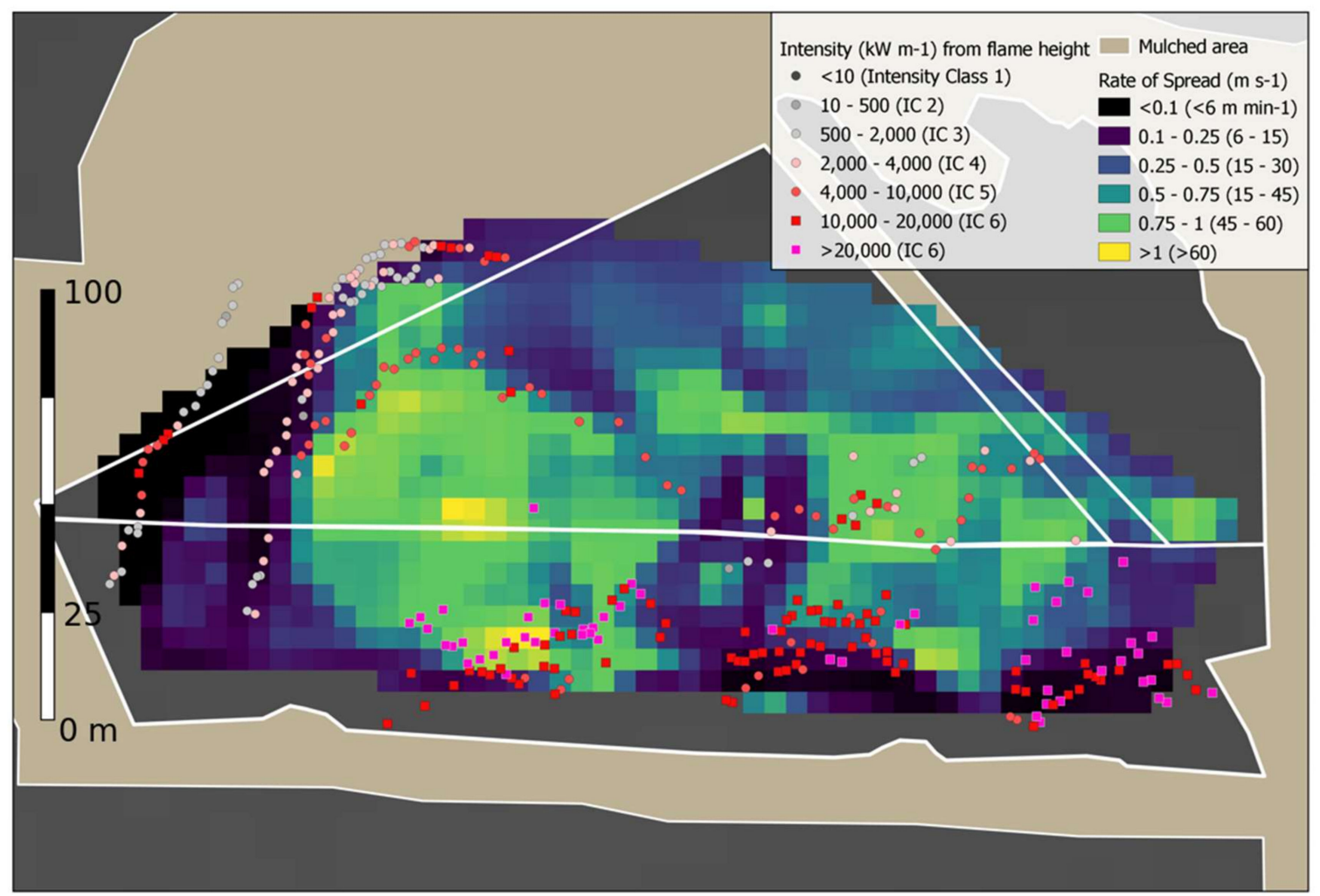

Figure 8. Fire intensity inferred by flame height from oblique aerial photography. Note that limited photographs were available to capture the flame heights, so large gaps between points exists.

Alternate fully independent methods of computing the relative fire intensity between the control and treatment are given in Table 1. Though these methods do not directly yield the same units as Byram's head fire intensity, the relative change between control and treatment is comparable. In-fire totalizing heat flux sensor (recording both convection and radiation) recorded a total heat flux at $30 \mathrm{~cm}$ height of $3.9 \mathrm{MJ} \mathrm{m}^{-2}$, and $29 \%$ of that value, or $1.1 \mathrm{MJ} \mathrm{m}^{-2}$, in the treatment. Overall, a calculation of Byram's head fire intensity where only foliage is considered (with the treatment having $52 \%$ of its canopy fuels removed by thinning) showed the greatest similarity to the independently measured relative intensity values of $34 \%$ and $29 \%$ using the observed flame height and in-stand heat flux sensors, respectively.

\section{Discussion}

\subsection{Contrasts with Other Experimental Fires}

Two test burns done in northwestern Canada in jack pine/black spruce stands that were also thinned resulted in a significant reduction of intensity and spread rate [18]. The natural stand in [18] and burn conditions were similar to those of the International Crown Fire Modelling Experiment (ICFME) test burns [27,41] and are as flammable as the Pelican Mountain fuels. Head fire intensities at ICFME exceeded $90,000 \mathrm{~kW} \mathrm{~m}^{-1}$ [41], with similar canopy fuel loads between the control plot and 
ICFME (1.3 vs. $1.6 \mathrm{~kg} \mathrm{~m}^{-2}$ ). The ICFME plots featured $5 \mathrm{~cm}$ of compact needle litter and a higher woody debris load in contrast to the $1 \mathrm{~kg} \mathrm{~m}^{-2}$ of consumed moss and duff and minor amounts of woody debris. The thinning work for the NWT burns was done during the summer, and full trees were skidded off site before being burned. As a result, the surface vegetation was heavily compacted, with sparse dead and down material either removed or lying flat on the surface. Comparatively, the surface fuels in this study were not treated or affected by tree removal since treatment was conducted manually and in winter. The importance of surface fuel treatment has also been shown in dry conifer work comparing fire behaviour between thinned stands with and without subsequent prescribed burns [42,43].

The comparable experimental fire in thinned black spruce in Alaska [19] is notable for the similar ecosystem, fuel loads, stem removal treatment, and control stand fire intensity over $30,000 \mathrm{~kW} \mathrm{~m}^{-1}$. The large reduction in fire intensity down to a surface fire $\left(160 \mathrm{~kW} \mathrm{~m}^{-1}\right)$ observed in [19] may be in part due to the higher moisture content in the important upper live moss (36\% vs. $7 \%$ in this study) and higher elevated fine fuel moisture (relative humidity $47 \%$ vs. $19 \%$ in this study). Moreover, greater fuel loads of live green vegetation (i.e., grasses and herbs) in the understory were likely present in [19] given the mid-June date of burn compared to mid-May in this study. Indeed, given the similarities in fuels and treatments, these two studies may represent both sides of a critical threshold of surface fuel moisture, below which this study was able to observe little impact of a fuel treatment compared to a control. Further examinations of fuel moisture and understory phenology effects need to be conducted in order to better understand the timing and duration of periods when thinning treatments in boreal spruce are expected to be of limited effectiveness.

The crown bulk density of the control stand $\left(0.28 \mathrm{~kg} \mathrm{~m}^{-3}\right.$; Table 1$)$ is in the mid-range of observed experimental fire crown bulk densities in active crown fires spreading on the order of $50 \mathrm{~m} \mathrm{~min}^{-1}$ [44]. The treatment crown bulk density of $0.10 \mathrm{~kg} \mathrm{~m}^{-3}$ is lower than any other experimental fire value for continuous crown fires with such high spread rates. Video documentation of the fire in the thinned stand shows that despite the high crown fraction burned, the continuity of flaming combustion and the base of the flames was observed in the surface fuels, and thus should not be considered an active crown fire.

\subsection{Fuel Moisture Considerations in Thinned Stands}

In fuel beds dominated by dead forest floor fuels, the litter moisture content is modified by the density of the tree canopy, with more open stands seeing drier surface fuels [7], in this case limited to feather mosses. Process-based models of understory dead fuel moisture point to both increased solar radiation and surface wind speeds as drivers of fuel drying [45]. The dominant surface cover in this study was a mix of Sphagnum mosses and feather mosses, both of which are living moss layers rather than a thin layer of dead material. Feather moss is adapted to low light conditions in more closed canopy forests and maintains a lower moisture content compared to Sphagnum mosses [9]. This consistently lower moisture content is far more sensitive to drought in comparison to Sphagnum mosses, and leads to depths of burn that are over ten times greater in feather moss compared to Sphagnum, supporting findings from free-burning wildfires in similar stands [46,47]. This inability of the dominant surface cover of feather moss to resist the greater evaporation rates in the canopy likely lead to the lower surface moss moisture contents in the treated stands. While this lower moisture content at the surface did not ultimately lead to greater depth burn (Figure 6), this drier surface likely provided a modest contribution to the surface fire intensity, as suggested by both the Canadian empirical Fire Behaviour Prediction System (FBP) [48] as well as the lab-based Rothermal model [49]. The contrast in measured dead surface litter moisture content (not including any feather moss, Figure 3a) (10\% vs. 7\%) measured pre-fire in this study would ideally yield a smaller contrast of $700 \mathrm{~kW} \mathrm{~m}^{-1} \mathrm{vs} .1900 \mathrm{~kW} \mathrm{~m}^{-1}$ following the Canadian FBP, roughly consistent with observed intensity trends in this study. In the Canadian FBP System, the reduction of surface feather moss moisture content from $18 \%$ in the control to $6 \%$ as observed in the treatment (Figure 3b), if applied to the spread model of dead surface fuels in the understory of mature white or red pine (C-5) would see a contrasting fire intensity of a low $70 \mathrm{~kW} \mathrm{~m}^{-1}$ 
(control) to over $2400 \mathrm{~kW} \mathrm{~m}^{-1}$ (treatment). Similarly, a contrast in surface fire rate of spread would be expected from $0.24 \mathrm{~m} \mathrm{~min}^{-1}$ to $8 \mathrm{~m} \mathrm{~min}^{-1}$, where none such occurred. Therefore, the outsized contrast in feather moss moisture content relative to the smaller differences in observed fire intensity suggests that increased feather moss consumption rates in the treatment did not translate to a faster rate of spread (Figure 5) but merely a modest increase in fire intensity at the surface, which partially compensated for a lower canopy fuel load (Table 1).

\subsection{Seasonally Frozen Organic Soils}

The depth of the concrete layer of seasonally frozen organic soil (depth to ice) varied considerably throughout the stand as a result of differences in surface elevation of peatland microtopography, but was in line with other early season measurements of depth to ice in other non-permafrost boreal peatlands [50]. Although seasonally frozen soil can be an input of water into the upper layers of peat [50] and/or act to limit drainage [51], there is little field observation of the persistence of this added moisture in a sub-humid environment such as the Boreal Plains, especially in periods of high fire weather where evaporation rates are towards their upper limits. In this instance, there is the potential for the layer of frozen soil to act as a barrier to an upward movement of (unfrozen) water from the water table, leading to enhanced drying of the uppermost surface layers. Whilst Sphagnum mosses limited depth of burn under the full range of depth to ice, depth of burn in feather moss dominated plots generally increased as depth to ice increased, suggesting the ice layer may act to limit the propagation of vertical burning (Figure 7).

\subsection{Evidence for Fire Intensity Changes}

The two independent observation methods that showed a reduction in fire intensity (in-fire heat flux sensors and photogrammetric flame lengths, Figure 8) points to meaningful intensity reductions of $50-70 \%$ (30-50\% of the untreated value) due to the tree thinning treatment applied the year prior. The photogrammetric flame lengths are not a systematic sample, however, and only represent snapshots in time during which aerial video was able to clearly observe flames during the helicopter's orbit around the fire. However, this intensity reduction still resulted in an Intensity Class $6\left(>10,000 \mathrm{~kW} \mathrm{~m}^{-1}\right.$, as calculated using Byram's equation) active crown fire with nearly complete consumption of the thinned crown. Fires, even of this reduced intensity in natural spruce stands, are at the upper limit of consistently effective aerial suppression at the fire's head, while fires at or beyond the $>17,000 \mathrm{~kW} \mathrm{~m}^{-1}$ range are beyond direct aerial suppression by water or retardant [52]. Conceptually, air tankers would deliver more water or retardant to the surface in thinned stands, analogous to enhanced rainfall, reaching the surface in more open forests [53].

\subsection{Inferring Rate of Spread from Combined Aerial and Ground Data}

Fire perimeter observations (infrared and oblique imagery) and point-based observations (thermocouples) of arrival time were combined into a discontinuous grid surface prior to interpolation. One complication with such inputs is that the line and point observations have inherently different levels of spatial and temporal accuracy. Historical fire behaviour sampling designs employed arrival times along a transect or sparse grid to estimate spread rate and acceleration on experimental fires [54,55]. In contrast, observations on free-burning wildfires often consisted of several points indicating head fire position at separate moments in time [56]. Grids permit more accurate and representative estimates of rate of spread than a transect [57], and increased sampling allows for a characterization of spread rate variability within the burn plot [58]. A study of flame front measurement observed arrival times on a fine spatio-temporal scale $(10-\mathrm{cm}$ pixels, $10 \mathrm{~Hz})$ using an outdoor burn platform, and suggested that the various calculation methods produced significantly different estimates of the spread rate, in part due to differences in the estimated direction of spread vectors [59]. With the primary focus of this study being within plot variability of spread rate, the choice of calculation method is likely less important. 


\section{Conclusions}

An experimental crown fire was ignited in a natural lowland boreal spruce forest in Alberta, Canada, in May 2019. The continuous crown fire burned into a thinned spruce stand with little alteration in spread rate or total fuel consumption. Spread rates in the treatment were similar to a natural boreal spruce fuel model (C-2) given the fuel moisture and wind speed including gusts. Despite drier surface fuels in the treated area due to increased sun and wind exposure, the final depth of consumption of the ground layer of mosses remained unchanged and was dominated by the consumption of feather moss. Any increase in surface fire intensity due to drier surface fuels did not compensate for the decrease in canopy fuel load (and consumption) from the thinning, leading to a net decrease in fire intensity as measured by flame heights and in-stand heat fluxes. Thinning work was done in winter and resulted in an uncompacted surface fuel bed that was vulnerable to drying and able to sustain the rate of spread. While fire spread rate changed little, the marked decrease in intensity and increased canopy openness from the thinning treatment suggests that direct suppression (i.e., sprinklers, mechanical fire guard, or aerial suppression with water, foam, or retardant) may be enhanced even under dry and windy conditions. Future studies should focus more on the role of active suppression measures and their interaction with fuel treatments, rather than fuel treatments as fully passive fire suppression strategies. New methodologies need to be developed to quantitatively integrate fuel consumption, fire energy, and rate of spread observations across the spectrum of flaming and smouldering. Additional work should be done on the potential for economically reducing the flammability of surface fuels in previously thinned black spruce stands.

Supplementary Materials: The following are available online at http://www.mdpi.com/2571-6255/3/3/28/s1.

Author Contributions: Conceptualization, D.K.T., S.L.W., H.C., R.H., G.M., B.M., R.R., T.S. and G.J.V.; Data curation, D.S., S.L.W., G.B., G.M., B.M., R.R., C.R., T.S., G.J.V. and J.Z.; Formal analysis, D.K.T., D.S., S.L.W., Q.B., G.B., H.C., R.H., G.M., B.M., R.R., C.R., T.S., G.J.V. and J.Z.; Funding acquisition, D.S.; Investigation, D.K.T., D.S., S.L.W., G.B., H.C., R.H., G.M., B.M. and R.R.; Methodology, D.K.T., D.S., S.L.W., Q.B., H.C., R.H., R.R., C.R. and G.J.V.; Project administration, D.K.T. and D.S.; Supervision, D.K.T. and D.S.; Visualization, D.K.T. and Q.B.; Writing-original draft, D.K.T., D.S., S.L.W., Q.B., G.B., H.C., B.M., R.R., C.R., T.S., G.J.V. and J.Z.; Writing一review and editing, D.K.T., D.S., S.L.W., G.B., H.C., R.R. and C.R. All authors have read and agreed to the published version of the manuscript.

Funding: This research received no external funding.

Acknowledgments: The Alberta Wildfire Management Branch created and supported this prescribed burning through planning, logistics, and operations. The Incident Management Team, as well as all the firefighters and support staff are acknowledged for their hard work and flexibility around scientific objectives. Alberta-Pacific Forest Industries Inc. provided in-kind support via a modified harvest of the aspen stands surrounding the burn unit. Bigstone Cree First Nation provided crews to do the thinning work and essential firefighting staff and community support for the project. Chris Stockdale assisted in the monoplotting of oblique fire behaviour photos. Hopkinson and Chasmer from the University of Lethbridge collected the airborne LiDAR data. Josh Johnston provided helpful discussions on airborne data collection.

Conflicts of Interest: The authors declare no conflict of interest.

Data Availability: Fuels sampling methods, as well as geospatial and weather data describing the fuels and fire progression are available at: https://doi.org/10.5281/zenodo.3745537.

\section{References}

1. Syphard, A.D.; Keeley, J.E. Factors Associated with Structure Loss in the 2013-2018 California Wildfires. Fire 2019, 2, 49. [CrossRef]

2. Alexandre, P.M.; Stewart, S.I.; Keuler, N.S.; Clayton, M.K.; Mockrin, M.H.; Bar-Massada, A.; Syphard, A.D.; Radeloff, V.C. Factors related to building loss due to wildfires in the conterminous United States. Ecol. Appl. 2016, 26, 2323-2338. [CrossRef] [PubMed]

3. Boer, M.M.; Sadler, R.J.; Wittkuhn, R.S.; McCaw, L.; Grierson, P.F. Long-term impacts of prescribed burning on regional extent and incidence of wildfires-Evidence from 50 years of active fire management in SW Australian forests. Ecol. Manag. 2009, 259, 132-142. [CrossRef] 
4. Parsons, R.A.; Pimont, F.; Wells, L.; Cohn, G.; Jolly, W.M.; de Coligny, F.; Rigolot, E.; Dupuy, J.-L.; Mell, W.; Linn, R.R. Modeling thinning effects on fire behavior with STANDFIRE. Ann. Sci. 2018, 75, 7. [CrossRef]

5. Whitman, E.; Parisien, M.-A.; Thompson, D.K.; Hall, R.J.; Skakun, R.S.; Flannigan, M.D. Variability and drivers of burn severity in the northwestern Canadian boreal forest. Ecosphere 2018, 9, e02128. [CrossRef]

6. Cruz, M.G.; Alexander, M.E.; Wakimoto, R.H. Modeling the Likelihood of Crown Fire Occurrence in Conifer Forest Stands. Science 2004, 50, 640-658. [CrossRef]

7. Wotton, B.M.; Beverly, J.L. Stand-specific litter moisture content calibrations for the Canadian Fine Fuel Moisture Code. Int. J. Wildland Fire 2007, 16, 463-472. [CrossRef]

8. Thompson, D.K.; Studens, J.; Krezek-Hanes, C.; Wotton, B.M. The impact of root exclusion on duff moisture and fire danger. Can. J. Res. 2015, 45, 978-986. [CrossRef]

9. Williams, T.G.; Flanagan, L.B. Effect of changes in water content on photosynthesis, transpiration and discrimination against ${ }^{13} \mathrm{CO}_{2}$ and $\mathrm{C}^{18} \mathrm{O}^{16} \mathrm{O}$ in Pleurozium and Sphagnum. Oecologia 1996, 108, 38-46. [CrossRef] [PubMed]

10. Prat-Guitart, N.; Rein, G.; Hadden, R.M.; Belcher, C.M.; Yearsley, J.M. Propagation probability and spread rates of self-sustained smouldering fires under controlled moisture content and bulk density conditions. Int. J. Wildland Fire 2016, 25, 456-465. [CrossRef]

11. Jandt, R.; Barnes, J.L.; Horschel, E. Forest Floor Moisture Content and Fire Danger Indices in Alaska; U.S. Bureau of Land Management: Washington, DC, USA, 2005.

12. Hirsch, K.G.; Corey, P.N.; Martell, D.L. Using Expert Judgment to Model Initial Attack Fire Crew Effectiveness. Science 1998, 44, 539-549. [CrossRef]

13. Hirsch, K.G.; Podur, J.J.; Janser, R.F.; McAlpine, R.S.; Martell, D.L. Productivity of Ontario initial-attack fire crews: Results of an expert-judgement elicitation study. Can. J. Res. 2004, 34, 705-715. [CrossRef]

14. Ponto, R.L. Bulldozer Production Rates and Guidelines for Constructing Fireguard in Boreal Forest Covertypes; Canada-Alberta Forest Resource Development Agreement; Forestry Canada: Edmonton, AB, Canada, 1989; ISBN 0-662-17140-3.

15. Agee, J.K.; Bahro, B.; Finney, M.A.; Omi, P.N.; Sapsis, D.B.; Skinner, C.N.; van Wagtendonk, J.W.; Phillip Weatherspoon, C. The use of shaded fuelbreaks in landscape fire management. Ecol. Manag. 2000, 127, 55-66. [CrossRef]

16. Campbell, M.J.; Page, W.G.; Dennison, P.E.; Butler, B.W. Escape Route Index: A Spatially-Explicit Measure of Wildland Firefighter Egress Capacity. Fire 2019, 2, 40. [CrossRef]

17. Miller, E.A.; Barnes, D.E. Research Summary: Quantification of Sprinkler Effects in Alaskan Feathermoss Fuel Beds; Alaska Fire Science Consortium: Fairbanks, AK, USA, 2018; p. 6.

18. Schroeder, D. Fire Behaviour in Thinned Jack Pine: Two Case Studies of FireSmart Treatments in Canada's Northwest Territories; FP Innovations: Vancouver, BC, Canada, 2010; p. 12.

19. Butler, B.W.; Ottmar, R.D.; Rupp, T.S.; Jandt, R.; Miller, E.; Howard, K.; Schmoll, R.; Theisen, S.; Vihnanek, R.E.; Jimenez, D. Quantifying the effect of fuel reduction treatments on fire behavior in boreal forests. Can. J. Res. 2012, 43, 97-102. [CrossRef]

20. Mooney, C. Can Light Stand Thinning Weaken an Advancing Crown Fire? A Case Study in Black Spruce (Picea mariana); FP Innovations: Hinton, AB, Canada, 2013.

21. Harris, C.; Fremont, L.; Price, O.; Boehr, W. 14LA-Lagoon Fire Case Study: How Fuel Treatment Areas Affect Wildland Urban Interface Areas; Government of Saskatchewan: Prince Albert, SK, Canada, 2015.

22. Fromm, M.; Lindsey, D.T.; Servranckx, R.; Yue, G.; Trickl, T.; Sica, R.; Doucet, P.; Godin-Beekmann, S. The Untold Story of Pyrocumulonimbus. Bull. Am. Meteorol. Soc. 2010, 91, 1193-1210. [CrossRef]

23. Benscoter, B.W.; Wieder, R.K. Variability in organic matter lost by combustion in a boreal bog during the 2001 Chisholm fire. Can. J. Res. 2003, 33, 2509-2513. [CrossRef]

24. Erni, S.S.; Wang, X.; Taylor, S.; Boulanger, Y.; Swystun, T.; Flannigan, M.; Parisien, M.-A. Developing a two-level fire regime zonation system for Canada. Can. J. Res. 2019. [CrossRef]

25. McGee, T.; McFarlane, B.; Tymstra, C. Chapter 3-Wildfire: A Canadian Perspective. In Wildfire Hazards, Risks and Disasters; Shroder, J.F., Paton, D., Eds.; Elsevier: Oxford, UK, 2015; pp. 35-58. ISBN 978-0-12-410434-1.

26. McGaughey, R.J. FUSION/LDV: Software for LIDAR Data Analysis and Visualization. 2020; p. 217. Available online: http://forsys.sefs.uw.edu/software/fusion/FUSION_manual.pdf (accessed on 30 May 2020). 
27. Alexander, M.E.; Stefner, C.N.; Mason, J.A.; Stocks, B.J.; Hartley, G.R.; Maffey, M.E.; Wotton, B.M.; Taylor, S.W.; Lavoie, N.; Dalrymple, G.N. Characterizing the jack pine-black spruce fuel complex of the International Crown Fire Modelling Experiment (ICFME); Information Report; Canadian Forest Service: Edmonton, AB, Canada, 2004; ISBN 0-662-37422-3.

28. Lukenbach, M.C.; Hokanson, K.J.; Devito, K.J.; Kettridge, N.; Petrone, R.M.; Mendoza, C.A.; Granath, G.; Waddington, J.M. Post-fire ecohydrological conditions at peatland margins in different hydrogeological settings of the Boreal Plain. J. Hydrol. 2017, 548, 741-753. [CrossRef]

29. Foken, T. Micrometeorology; Springer: Berlin/Heidelberg, Germany, 2017; ISBN 978-3-642-25440-6.

30. Krautz, J. Appendix C-Insulated Boxes for Protecting Video Cameras. In Surviving Fire Entrapments Comparing Conditions Inside Vehicles and Fire Shelters; USDA Forest Service: Washington, DC, USA, 1997; pp. $39-40$. Available online: https://www.fs.fed.us/eng/pubs/htmlpubs/htm97512817/ (accessed on 30 May 2020).

31. Sullivan, E.A.; McDonald, A.G. Mathematical model and sensor development for measuring energy transfer from wildland fires. Int. J. Wildland Fire 2014, 23, 995-1004. [CrossRef]

32. Bozzini, C.; Conedera, M.; Krebs, P. A New Monoplotting Tool to Extract Georeferenced Vector Data and Orthorectified Raster Data from Oblique Non-Metric Photographs. Int. J. Herit. Digit. Era 2012, 1, 499-518. [CrossRef]

33. Butler, B.W.; Finney, M.A.; Andrews, P.L.; Albini, F.A. A radiation-driven model for crown fire spread. Can. J. Res. 2004, 34, 1588-1599. [CrossRef]

34. Taylor, S.W.; Alexander, M.E. Field Guide to the Canadian Forest Fire Behavior Prediction (FBP) System, 3rd ed.; Canadian Forest Service: Edmonton, AB, Canada, 2018; Volume 11, ISBN 978-0-66004-333-3.

35. Waddington, J.M.; Thompson, D.K.; Wotton, M.; Quinton, W.L.; Flannigan, M.D.; Benscoter, B.W.; Baisley, S.A.; Turetsky, M.R. Examining the utility of the Canadian Forest Fire Weather Index System in boreal peatlands. Can. J. Res. 2012, 42, 47-58. [CrossRef]

36. Makkonen, L. Plotting Positions in Extreme Value Analysis. J. Appl. Meteorol. Clim.. 2006, 45, 334-340. [CrossRef]

37. Elmes, M.C.; Thompson, D.K.; Sherwood, J.H.; Price, J.S. Hydrometeorological conditions preceding wildfire, and the subsequent burning of a fen watershed in Fort McMurray, Alberta, Canada. Nat. Hazards Earth Syst. Sci. 2018, 18, 157-170. [CrossRef]

38. Wilkinson, S.L.; Moore, P.A.; Flannigan, M.D.; Wotton, B.M.; Waddington, J.M. Did enhanced afforestation cause high severity peat burn in the Fort McMurray Horse River wildfire? Environ. Res. Lett. 2018, 13, 014018. [CrossRef]

39. Nuñez, J.R.; Anderton, C.R.; Renslow, R.S. Optimizing colormaps with consideration for color vision deficiency to enable accurate interpretation of scientific data. PLOS ONE 2018, 13, e0199239. [CrossRef] [PubMed]

40. Wilkinson, S.L.; Moore, P.A.; Thompson, D.K.; Wotton, B.M.; Hvenegaard, S.; Schroeder, D.; Waddington, J.M. The effects of black spruce fuel management on surface fuel condition and peat burn severity in an experimental fire. Can. J. Res. 2018, 48, 1433-1440. [CrossRef]

41. Stocks, B.J.; Alexander, M.E.; Wotton, B.M.; Stefner, C.N.; Flannigan, M.D.; Taylor, S.W.; Lavoie, N.; Mason, J.A.; Hartley, G.R.; Maffey, M.E.; et al. Crown fire behaviour in a northern jack pine-Black spruce forest. Can. J. Res. 2004, 34, 1548-1560. [CrossRef]

42. Piqué, M.; Domènech, R. Effectiveness of mechanical thinning and prescribed burning on fire behavior in Pinus nigra forests in NE Spain. Sci. Total Environ. 2018, 618, 1539-1546. [CrossRef]

43. Prichard, S.J.; Povak, N.A.; Kennedy, M.C.; Peterson, D.W. Fuel treatment effectiveness in the context of landform, vegetation, and large, wind-driven wildfires. Ecol. Appl. 2020, 30, e02104. [CrossRef] [PubMed]

44. Cruz, M.G.; Alexander, M.E.; Wakimoto, R.H. Development and testing of models for predicting crown fire rate of spread in conifer forest stands. Can. J. Res. 2005, 35, 1626-1639. [CrossRef]

45. Van der Kamp, D.W.; Moore, R.D.; McKendry, I.G. A model for simulating the moisture content of standardized fuel sticks of various sizes. Agric. For. Meteorol. 2017; 236, 123-134.

46. Shetler, G.; Turetsky, M.R.; Kane, E.; Kasischke, E. Sphagnum mosses limit total carbon consumption during fire in Alaskan black spruce forests. Can. J. Res. 2008, 38, 2328-2336. [CrossRef]

47. Terrier, A.; de Groot, W.J.; Girardin, M.P.; Bergeron, Y. Dynamics of moisture content in spruce-feather moss and spruce-Sphagnum organic layers during an extreme fire season and implications for future depths of burn in Clay Belt black spruce forests. Int. J. Wildland Fire 2014, 23, 490-502. [CrossRef] 
48. Forestry Canada Fire Danger Rating Group Development and structure of the Canadian Forest Fire Behavior Prediction System. Forestry Canada: Ottawa, ON, Canada, 1992; Volume ST-X-3, ISBN 0-662-19812-3.

49. Andrews, P.L. The Rothermel Surface Fire Spread Model and Associated Developments: A Comprehensive Explanation; General Technical Report RMRS-GTR-371; U.S. Department of Agriculture, Forest Service, Rocky Mountain Research Station: Fort Collins, CO, USA, 2018.

50. Huizen, B.V.; Petrone, R.M.; Price, J.S.; Quinton, W.L.; Pomeroy, J.W. Seasonal ground ice impacts on spring ecohydrological conditions in a western boreal plains peatland. Hydrol. Process. 2020, 34, 765-779. [CrossRef]

51. Kasischke, E.S.; Turetsky, M.R.; Kane, E.S. Effects of trees on the burning of organic layers on permafrost terrain. Ecol. Manag. 2012, 267, 127-133. [CrossRef]

52. Quintilio, D.; Anderson, A.W. Simulation study of initial attack fire operations in the Whitecourt Forest, Alberta; Canadian Forestry Service: Edmonton, AB, Canada, 1976.

53. Carlyle-Moses, D.E.; Gash, J.H.C. Rainfall Interception Loss by Forest Canopies. In Forest Hydrology and Biogeochemistry: Synthesis of Past Research and Future Directions; Levia, D.F., Carlyle-Moses, D., Tanaka, T., Eds.; Ecological Studies; Springer: Dordrecht, The Netherlands, 2011; pp. 407-423. ISBN 978-94-007-1363-5.

54. Simard, A.J.; Eenigenburg, J.E.; Adams, K.B.; Nissen, R.L.; Deacon, A.G. A General Procedure for Sampling and Analyzing Wildland Fire Spread. Science 1984, 30, 51-64. [CrossRef]

55. McAlpine, R.S.; Wakimoto, R.H. The Acceleration of Fire from Point Source to Equilibrium Spread. Science 1991, 37, 1314-1337. [CrossRef]

56. Alexander, M.E.; Quintilio, D. Perspectives on experimental fires in Canadian forestry research. Math. Comput. Model. 1990, 13, 17-26. [CrossRef]

57. Simard, A.J.; Deacon, A.G.; Adams, K.B. Nondirectional sampling of wildland fire spread. Fire Technol. 1982, 18, 221-228. [CrossRef]

58. McRae, D.J.; Jin, J.-Z.; Conard, S.G.; Sukhinin, A.I.; Ivanova, G.A.; Blake, T.W. Infrared characterization of fine-scale variability in behavior of boreal forest fires. Can. J. Res. 2005, 35, 2194-2206. [CrossRef]

59. Johnston, J.M.; Wheatley, M.J.; Wooster, M.J.; Paugam, R.; Davies, G.M.; DeBoer, K.A. Flame-Front Rate of Spread Estimates for Moderate Scale Experimental Fires Are Strongly Influenced by Measurement Approach. Fire 2018, 1, 16. [CrossRef]

(C) 2020 by the authors. Licensee MDPI, Basel, Switzerland. This article is an open access article distributed under the terms and conditions of the Creative Commons Attribution (CC BY) license (http://creativecommons.org/licenses/by/4.0/). 